\title{
POLLEN OF SOUTHEAST ASIAN ALCHORNEA (EUPHORBIACEAE), WITH AN OVERVIEW OF THE POLLEN FOSSIL RECORD
}

\author{
L.J. BULALACAO ${ }^{1} \&$ R.W.J.M. VAN DER HAM \\ Nationaal Herbarium Nederland, Universiteit Leiden branch, P.O. Box 9514, \\ 2300 RA Leiden, The Netherlands; e-mail: ham@nhn.leidenuniv.nl
}

\begin{abstract}
SUMMARY
In order to evaluate pollen morphological descriptions of Alchornea in the literature, which are almost completely based on African and American species, the pollen of eight Southeast Asian species of Alchornea was investigated, using light and scanning electron microscopy. Very little variation appeared to be present in the Asian material. Slightly deviating from the scabrate ornamentation type are A. kelungensis (psilate) and A. rugosa (striate-rugulate). The scabrate type is also found in A. castaneaefolia (Brazil), A. hirtella (Liberia) and A.obovata (Colombia). The operculate Alchornea pollen type, which can be easily recognised using light microscopy, seems to represent a diagnostic character for the tribe Alchornieae (pollen of Bossera unknown). Its characteristic appearance resulted in a relatively extensive fossil record. The earliest records are from the Middle Eocene of Venezuela and Nigeria, while records for Australia and Borneo date from the mid-Tertiary and the Neogene (Miocene-Pliocene), respectively. These records suggest that the tribe Alchornieae has an AfricanAmerican Gondwanic origin, and reached its pantropic distribution at least in the mid-Tertiary.
\end{abstract}

Key words: Alchornea, Euphorbiaceae, fossil record, pollen, SE Asia.

\section{INTRODUCTION}

The Alchornieae are a tribe of nine genera (c. 96 spp.), Alchornea, Aparisthmium, Bocquillonia, Bossera, Caelebogyne, Conceveiba, Gavarretia, Orfilea and Polyandra, belonging to subfamily Acalyphoideae of the Euphorbiaceae (Radcliffe-Smith, 2001). Of these genera, Alchornea is the largest and most widespread, containing c. 60 species and having a pantropical distribution. The other genera are much smaller, containing from 1 to 14 species. They are restricted to America, Madagascar, Australia or New Caledonia.

Pollen morphologically, subfamily Acalyphoideae is the most heterogeneous of the five subfamilies of the Euphorbiaceae (Punt, 1987; Takahashi et al., 1995, 2000; Nowicke et al., 1998, 1999; Nowicke \& Takahashi, 2002). Pollen of tribe Alchornieae was described by Punt (1962: 7 genera, 14 species, illustrated with drawings), Taka-

1) Dr. Lolita J. Bulalacao was the head of the Palynology Unit of the Botany Division of the National Museum, Manila, Philippines, and studied Alchornea pollen at the Nationaal Herbarium Nederland, Leiden during the summer of 2001, when she was already suffering from a severe illness. She died on 16 October 2002. The second author took it on him to complete the study, remembering a brave woman. 

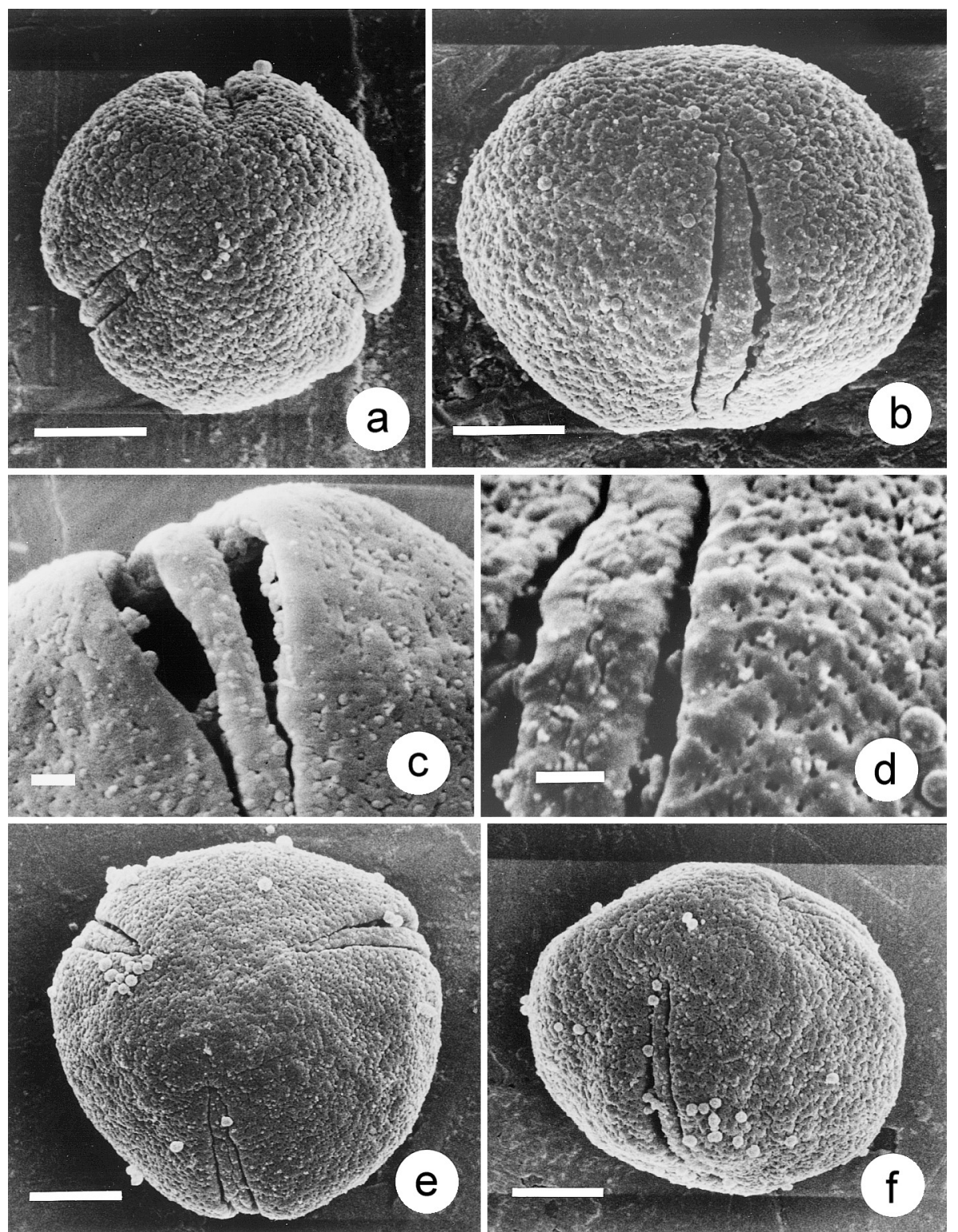

Fig.1. Scanning electron micrographs of Alchornea pollen. - a-c. A. borneensis Pax \& K. Hoffm. a. Polar view; b. equatorial view; c. detail showing ornamentation, operculum and two Ubisch bodies (at the right). - d. A. kelungensis Hayata, detail showing ornamentation and operculum. e, f. A. parviflora Müll.Arg. e. Polar view; f. equatorial view (note the Ubisch bodies). - Scale bars: $\mathrm{a}, \mathrm{b}, \mathrm{e}, \mathrm{f}=5 \mu \mathrm{m} ; \mathrm{c}, \mathrm{d}=1 \mu \mathrm{m}$. 
hashi et al. (1995: 5 genera, 15 species, illustrated with SEM and TEM images) and Takahashi et al. (2000: 7 genera, 29 species, illustrated with SEM and TEM images). No material of Bossera and Polyandra was available. The most exhaustive of these studies, Takahashi et al. (2000), includes 13 Alchornea species of which only two come from SE Asia: A. kelungensis (= A. trewioides; Ishigaki Island, east of Taiwan) and A. rugosa (New Guinea). Few pollen floras are available for Southeast Asian regions. None treat more than three Alchornea species: Ikuse (1956; no illustrations), Ting (1949; with drawings) and Yu \& Long (1982; with LM images). To complement the data in these works, a special study was made of the pollen of a number of Southeast Asian Alchornea species, concurrently with a taxonomic revision of Alchornea in Malesia and Thailand (Bulalacao \& Van Welzen, in prep.).

\section{MATERIAL AND METHODS}

Mature male flower buds were removed from the following herbarium material (all in L):

- Alchornea adenophylla Pax \& K. Hoffm., Meijer 7128, Sumatra, Indonesia

- Alchornea borneensis Pax \& K. Hoffm., SHEA 27713, Kalimantan, Indonesia

- Alchornea kelungensis Hayata, Tanaka \& Shimada 13513, Taiwan

- Alchornea parviflora Müll.Arg., Merrill 2095, Palawan, Philippines

- Alchornea rhodophylla Pax \& K. Hoffm., SF 39080, Penang, Malaysia

- Alchornea rugosa (Lour.) Müll.Arg., Cheviwat \& Nimanog 44, Thailand

- Alchornea rugosa (Lour.) Müll.Arg., Maxwell 87-443, Thailand

- Alchornea rugosa (Lour.) Müll.Arg., Meijer 1782, Java, Indonesia

- Alchornea tiliifolia (Benth.) Müll.Arg., Kerr 18467, Thailand

- Alchornea trewioides (Benth.) Müll.Arg., Walker \& Tawada 7175, Ishigaki Isl., Japan

All samples were prepared for light microscopy (LM) and scanning electron microscopy (SEM), according to the techniques described by Van der Ham (1990). Ten pollen grains per sample were measured. The terminology used follows Punt et al. (1994).

\section{RESULTS}

\section{Pollen of Southeast Asian species of Alchornea - Fig. 1, 2; Table 1}

Pollen grains isopolar, suboblate to prolate spheroidal. Equatorial outline obtusely triangular. Polar axis $(\mathrm{P})=16(20.5) 27 \mu \mathrm{m}$, equatorial diameter $(\mathrm{E})=18$ (22.8) 30 $\mu \mathrm{m}, \mathrm{P} / \mathrm{E}=0.86(0.90) 1.03$.

Aperture system 3-colporate. Ectoapertures distinct operculate colpi, 6-16 $\mu \mathrm{m}$ long. Operculum elongate, towards the poles hardly or not connected to the non-apertural sexine. Margo absent. Endoapertures lalongate, often indistinct pori or colpi without costae, $1-4$ by $6-13 \mu \mathrm{m}$. Fastigium-like cavities present, filled with relatively long columellae (Fig. 2h). 

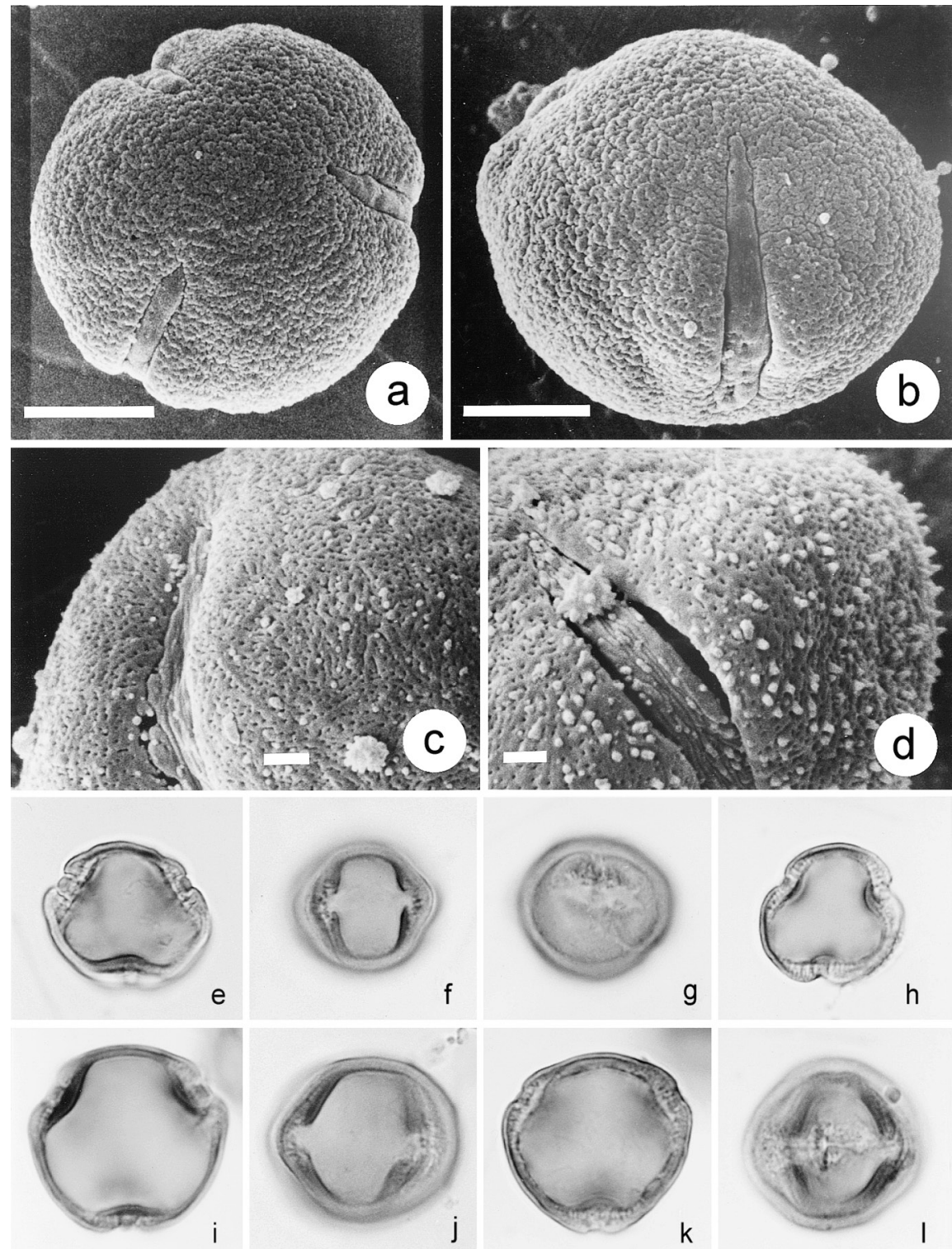

$\mathrm{h}$

Fig. 2. Scanning electron (a-d) and light (e-1) micrographs of Alchornea pollen. - a, b. A.rhodophylla Pax \& K. Hoffm. a. Polar view; b. equatorial view. - c. A. rugosa (Lour.) Müll.Arg. (Maxwell 87-443), detail showing ornamentation and operculum (note the Ubisch bodies). - d. A. rugosa (Lour.) Müll.Arg. (Meijer 1782), detail showing ornamentation and operculum (note the Ubisch body on the operculum). - e-g. A. rhodophylla Pax \& K. Hoffm. e. Polar view; f. equatorial view; g. equatorial view showing endoaperture. - h. A. rugosa (Lour.) Müll.Arg. (Maxwell 87-443), polar view (note the relatively long columellae near the apertures). - i, j. A. tiliifolia (Benth.) Müll.Arg. i. Polar view; j. equatorial view. - k, 1. A. trewioides (Benth.) Müll.Arg. k. Polar view; l. equatorial view. - Scale bars: $\mathrm{a}, \mathrm{b}=5 \mu \mathrm{m} ; \mathrm{c}, \mathrm{d}=1 \mu \mathrm{m} ; \mathrm{e}-1=1000 \mathrm{x}$. 
Mesocolpial exine 2-3 $\mu \mathrm{m}$ thick. Sexine thicker, equal to, or thinner than nexine. Infratectum thin, columellate, thickening near the endoapertures, showing distinctly longer columellae at both lateral sides of the endoapertures (fastigium-like cavities).

Ornamentation mostly scabrate-perforate (Fig. 1c), sometimes almost psilate-perforate (A. kelungensis; Fig. 1d) or striate-rugulate (A. rugosa; Fig. 2c, d). Operculum with hardly any perforations, usually scabrate or indistinctly striate, sometimes psilate (A. kelungensis) or more distinctly striate (A.rugosa). Psilate to scabrate Ubisch bodies often present (Fig. 1c, e, f; 2c, d).

Pollen data of the individual species are provided in Table 1.

Table 1. Pollen data of Southeast Asian Alchornea species. $\mathrm{P}=$ length of polar axis, $\mathrm{E}=$ equatorial diameter. All sizes are in $\mu \mathrm{m}$.

\begin{tabular}{|c|c|c|c|c|c|c|}
\hline & $\mathrm{P}$ & E & $\mathrm{P} / \mathrm{E}$ & $\begin{array}{l}\text { colpus } \\
\text { length }\end{array}$ & $\begin{array}{l}\text { endoaperture } \\
\text { size }\end{array}$ & ornamentation \\
\hline A. adenophylla & 16.0 & 20.6 & 0.92 & & & scabrate-perforate \\
\hline A. borneensis & 20.3 & 22.0 & 0.92 & $7-11$ & $1-2$ by $8-10$ & scabrate-perforate \\
\hline A. kelungensis & 23.0 & 26.2 & 0.88 & & 2 by 8 & psilate-perforate \\
\hline A. parviflora & 19.5 & 22.7 & 0.86 & $6-12$ & $1-3$ by $8-10$ & scabrate-perforate \\
\hline A. rhodophylla & 21.6 & 23.7 & 0.91 & $13-15$ & $1-4$ by $8-10$ & scabrate-perforate \\
\hline A.rugosa & 18.5 & 20.0 & 0.92 & $11-12$ & $1-3$ by $7-13$ & striate-rugulate \\
\hline A. tiliifolia & 23.9 & 26.7 & 0.89 & $14-16$ & $2-4$ by $7-10$ & scabrate-perforate \\
\hline A.trewioides & 21.8 & 21.2 & 1.03 & $10-12$ & $2-3$ by $6-10$ & scabrate-perforate \\
\hline
\end{tabular}

DISCUSSION

\section{Genus Alchornea}

Within the group of Southeast Asian species studied, very little pollen morphological variation occurs. Slightly deviating from the scabrate species are A. kelungensis (psilate) and $A$. rugosa (all three collections striate-rugulate). In comparing with the species studied by Takahashi et al. $(1995,2000)$, the scabrate ornamentation type occurring in most Southeast Asian species is found in A. castaneaefolia (Brazil), A. hirtella (Liberia) and A. obovata (Colombia); in the pollen of the other African and American species illustrated, the ornamentation elements are much more discrete. The occurrence in the Southeast Asian species studied of relatively long columellae in fastigium-like cavities at both lateral sides of each endoaperture, as described for the first time by Takahashi et al. $(1995,2000)$, is confirmed in the present study. The presence of a double columellate infratectum could not be demonstrated, as no transmission electron microscopy (TEM) examination was carried out.

\section{Tribe Alchornieae}

In the introduction, the paper by Takahashi et al. (2000) was cited as the most exhaustive of the studies dealing with Alchornieae, describing 29 species from seven of the 
nine genera, while no material of the monotypic genera Bossera and Polyandra was available. However, Punt (1962, p. 82) referred to a photograph of a pollen grain of Polyandra bracteosa (only known from the type) in the original description of the genus (Léal, 1951). However, the photograph is actually an informative drawing of a pollen grain. It shows a 3-colporate, operculate pollen grain of c. $33 \mu \mathrm{m}$.

The eight known genera of the Alchornieae share a characteristic pollen type: 3-(or 4-)colporate pollen grains with distinctly operculate colpi (Léal, 1951; Punt, 1962; Takahashi et al., 2000), which can easily be recognised using light microscopy. Punt (1962) included species of two genera in his Alchornea pollen type that do not belong to the tribe Alchornieae: Adenophaedra and Neotrewia, and which do not possess pollen with operculate colpi (Fernández-González \& Lobreau-Callen, 1996; Nowicke \& Takahashi, 2002). Thus, the operculate Alchornea pollen type seems to represent a diagnostic character for the tribe Alchornieae.

\section{Fossil record of the Alchornea pollen type}

The characteristic appearance of the operculate pollen grains of the tribe Alchornieae, using light microscopy, has resulted in a relatively extensive fossil record of the Alchornea pollen type. The fossil pollen has usually been attributed to the genus Alchornea, but actually it should be compared with the pollen of the entire tribe Alchornieae, as the genera are hard to separate. The earliest records (as Psilatricolporites operculatus) are those from the lower and upper part of the Middle Eocene of Venezuela and Nigeria, respectively (Germeraad et al., 1968; Muller, 1970). Slightly younger are the Late Eocene records from Brazil (Muller, 1981). Graham (1976, 1988a, b, 1989, 1991a, b), Graham \& Dilcher (1998) and Graham \& Jarzen (1969) gave records for the Oligocene, Miocene and Pliocene of Costa Rica, Mexico, Panama and Puerto Rico. Martin $(1974,1978)$ found the Alchornea pollen type in the mid-Tertiary of Australia, comparing it with the extant Australian genus Caelebogyne, while Germeraad et al. (1968) recognised it in unspecified Neogene (Miocene-Pliocene) sediments in Borneo. These records suggest that the tribe Alchornieae has an African-American Gondwanic origin, and reached its pantropic distribution at least in the mid-Tertiary.

\section{ACKNOWLEDGEMENTS}

Thanks are due to Bertie Joan van Heuven and Vernie Sagun for assistance, Ben Kieft for the plates, Peter van Welzen for taxonomic guidance, and the Nederlandse Organisatie voor Wetenschappelijk Onderzoek (NWO) for a visitor grant (B85-345) to the first author.

\section{REFERENCES}

Bulalacao, L.J. \& P.C. van Welzen. In prep. Revision of the genus Alchornea (Euphorbiaceae) in Thailand and Malesia. Blumea.

Fernández-González, D. \& D. Lobreau-Callen. 1996. Le pollen de la tribu des Acalypheae (Acalyphoideae, Euphorbiaceae). Grana 35: 266-284.

Germeraad, J.H., C.A. Hopping \& J. Muller. 1968. Palynology of Tertiary sediments from tropical areas. Rev. Palaeobot. Palynol. 6: 189-348.

Graham, A. 1976. Studies in neotropical paleobotany. II. The Miocene communities of Veracruz, Mexico. Ann. Missouri Bot. Gard. 63: 787-842. 
Graham,A. 1988a. Studies in neotropical paleobotany. V. The lower Miocene communities of Panama - the Culebra Formation. Ann. Missouri Bot. Gard. 75: 1440-1466.

Graham, A. 1988b. Studies in neotropical paleobotany. VI. The lower Miocene communities of Panama - the Cucaracha Formation. Ann. Missouri Bot. Gard. 75: 1467-1479.

Graham, A. 1989. Studies in neotropical paleobotany. VII. The lower Miocene communities of Panama - the La Boca Formation. Ann. Missouri Bot. Gard. 76: 50-66.

Graham, A. 1991a. Studies in neotropical paleobotany. VIII. The Pliocene communities of Panama - introduction and ferns, gymnosperms, and angiosperms (monocots). Ann. Missouri Bot. Gard. 78: $190-200$.

Graham, A. 1991b. Studies in neotropical paleobotany. IX. The Pliocene communities of Panama - angiosperms (dicots). Ann. Missouri Bot. Gard. 78: 201-223.

Graham. A. \& D.L. Dilcher. 1998. Studies in neotropical paleobotany. XII. A palynoflora from the Pliocene Rio Banano Formation of Costa Rica and the Neogene vegetation of Mesoamerica. Amer. J. Bot. 85: 1426-1438.

Graham,A.\& D.M. Jarzen. 1969. Studies in neotropical paleobotany. I. The Oligocene communities of Puerto Rico. Ann. Missouri Bot. Gard. 56: 308-357.

Ikuse, M. 1956. Pollen grains of Japan. Hirokawa Publishing Co., Tokyo.

Léal, C.G. 1951. Contribuição ao estudo da família Euphorbiaceae. Arch. Jard. Bot. Rio de Janeiro 11: $63-70$.

Martin, H.A. 1974. The identification of some Tertiary pollen belonging to the family Euphorbiaceae. Austral. J. Bot. 22: 271-291.

Martin, H.A. 1978. Evolution of the Australian flora and vegetation through the Tertiary: evidence from pollen. Alcheringa 2: 181-202.

Muller, J. 1970. Palynological evidence on early differentiation of angiosperms. Biol. Rev. 45: 417-450.

Muller, J. 1981. Fossil pollen records of extant angiosperms. Bot. Rev. (New York) 47: 1-142.

Nowicke, J.W. \& M. Takahashi. 2002. Pollen morphology, exine structure, and systematics of Acalyphoideae (Euphorbiaceae). Part 4. Tribes Acalypheae pro parte (Erythrococca, Claoxylon, Claoxylopsis, Mareya, Mareyopsis, Discoclaoxylon, Micrococca, Amyrea, Lobanilia, Mallotus, Deuteromallotus, Cordemoya, Coccoceras, Trewia, Neotrewia, Rockinghamia, Octospermum, Acalypha, Lasiococca, Spathiostemon, Homonoia), Plukenetieae (Haematostemon, Astrococcus, Angostyles, Romanoa, Eleutherostigma, Plukenetia, Vigia, Cnesmone, Megistostigma, Sphaerostylis, Tragiella, Platygyna, Tragia, Acidoton, Pachystylidium, Dalechampia), Omphaleae (Omphalea), and discussion and summary of the complete subfamily. Rev. Palaeobot. Palynol. 121: 231-336.

Nowicke, J.W., M. Takahashi \& G.L. Webster. 1998. Pollen morphology, exine structure, and systematics of Acalyphoideae (Euphorbiaceae). Part 1. Tribes Clutieae (Clutia), Pogonophoreae (Pogonophora), Chaetocarpeae (Chaetocarpus, Trigonopleura), Pereae (Pera), Cheiloseae (Cheilosa, Neoscortechinia), Erismantheae pro parte (Erismanthus, Moultonianthus), Dicoelieae (Dicoelia), Galearieae (Galearia, Microdesmis, Panda) and Ampereae (Ampera, Monotaxis). Rev. Palaeobot. Palynol. 102: 115-152.

Nowicke, J.W., M. Takahashi \& G.L. Webster. 1999. Pollen morphology, exine structure, and systematics of Acalyphoideae (Euphorbiaceae). Part 2. Tribes Agrostistachydeae (Agrostistachys, Pseudagrostistachys, Cyttaranthus, Chondrostylis), Chrozophoreae (Speranskia, Caperonia, Philyra, Ditaxis, Argythamnia, Malanolepis, Chrozophora), Bernardieae (Bernardia, Necepsia, Paranecepsia, Discocleidion, Adenophaedra) and Pycnocomeae (Pycnocoma, Drocetonicia, Argomuellera, Blumeodendron, Podadenia, Ptychopyxis, Botryophora). Rev. Palaeobot. Palynol. 105: $1-62$.

Punt, W. 1962. Pollen morphology of the Euphorbiaceae with special reference to taxonomy. Wentia 7: $1-116$.

Punt, W. 1987. A survey of pollen morphology in Euphorbiaceae with special reference to Phyllanthus. Bot. J. Linn. Soc. 94: 127-142.

Punt, W., S. Blackmore, S. Nilsson \& A. le Thomas. 1994. Glossary of pollen and spore terminology. LPP Contr. Ser. 1. LPP Foundation, Utrecht. 
Radcliffe-Smith, A. 2001. Genera Euphorbiacearum. Royal Botanic Gardens, Kew.

Takahashi, M., J.W. Nowicke \& G.L. Webster. 1995. A note on remarkable exines in Acalyphoideae (Euphorbiaceae). Grana 34: 282-290.

Takahashi, M., J.W. Nowicke, G.L. Webster, S.S. Orli \& S. Yanowski. 2000. Pollen morphology, exine structure, and systematics of Acalyphoideae (Euphorbiaceae). Part 3. Tribes Epiprineae (Epiprinus, Symphyllia, Adenochlaena, Cleidocarpon, Koilodepas, Cladogynos, Cephalocrotonopsis, Cephalocroton, Cephalomappa), Adelieae (Adelia, Crotonogynopsis, Enriquebeltrania, Lasiocroton, Leucocroton,), Alchorneae (Orfilea, Alchornea, Coelebogyne, Aparisthium, Bocquillonia, Conceveiba, Gavarretia), Acalypheae pro parte (Ricinus, Adriana, Mercurialis, Leidesia, Dysopsis, Wetria, Cleidion, Sampantaea, Macaranga). Rev. Palaeobot. Palynol. 110: 1-66.

Ting, S. 1949. Illustrations of pollen grains of some Chinese plants. Bot. Not. 1949: 277-282.

Van der Ham, R.W.J.M. 1990. Nephelieae pollen (Sapindaceae): form, function, and evolution. Leiden Bot. Ser. 13.

Yu, C.H. \& H. Long. 1982. Euphorbiaceae. In: Angiosperm pollen flora of tropic and subtropic China: 126-145. Inst. Bot. \& South China Inst. Bot. Academia Sinica. 